\title{
Parolization and Linguistics of Saying
}

\author{
Jorge Wiesse Rebagliati \\ Department of Humanities, Universidad del Pacífico, Lima, Perú
}

\section{Email address:}

wiesse_jr@up.edu.pe

\section{To cite this article:}

Jorge Wiesse Rebagliati. Parolization and Linguistics of Saying. International Journal of Language and Linguistics. Special Issue: Linguistics of Saying. Vol. 3, No. 6-1, 2015, pp. 112-116. doi: 10.11648/j.ijl1.s.2015030601.25

\begin{abstract}
Parolization, a term coined by Jürgen Trabant following Eugenio Coseriu's guidelines, consists in the actualization of a text -seen as Ferdinand de Saussure's langue- in reading or interpretation -seen as parole. This paper argues that parolization could be better understood if considered as an act of knowing, saying and speaking, that is, as the object of Linguistics of Saying. Aspects of this phenomenon are discussed and exemplified with literary texts (the Odissey, the Divine Comedy, La Celestina, the Cantar de Mio Cid, Rubén Darío's Prosas profanas and Antonio Machado's Soledades and Campos de Castilla).
\end{abstract}

Keywords: Linguistics of Saying, Parolization, Actualization of the text, Reading

\section{Introduction}

In his book Semiología de la obra literaria (1975), clearly following Coserian guidelines, Jürgen Trabant outlines a theory of Literature very close to the Romanian linguist's Linguistics of Speech. Trabant considers, for example, that the determination of the text aesthetic content is done through a subjective creative act (i.e., a speech act), a reading, which manifests itself in necessary imperfect paraphrases 1.

\section{Interpretation as Parolization}

These paraphrases are nothing but hermeneutic activity, that is, interpretation. In this sense, if Ferdinand de Saussure's langue/ parole dichothomy is applied creatively, the speech act, parole is interpretation, whereas the text is langue2. Trabant stresses the point:

Now then, between the substance of content (expressed in certain individual interpretations [i.e., the interpretations]) and the form of content (all possible interpretable units [i.e., the text]) a speech-language (or better: speech-system) relationship can be recognized as long as the interpretation (and also the sum of all interpretations) can actualize only one of the latent possibilities in the text. Just as the system is never actualized exhaustively in speech, interpretation never actualizes the system of possible units

1 Trabant 1975. p, 317.

2 Ibid. of the text's content 3 .

The activity of the interpreter, then, consists in a "parolization", a creative, historical, cognitive, expressive activity - the same as with every speech act - that transforms the virtual text in actual experience, in exegesis. There is, however, an important difference between interpreter and speaker, as Jürgen Trabant says:

The direction or the orientation of a designation - compared with the designative or appellative orientation of the speech act- is obviously in reverse: interpretation attributes "aesthetic things" to "aesthetic meanings" and not, as when in speaking, meanings to things. In speaking one searches words for things to designate; in interpretation, on the contrary, "things" to interpret "meanings". In interpretation, abstract meanings are embodied; in speaking, a language generalizes concrete themes or issues 4 .

\section{Two inter-connected theories}

We believe that the phenomenon of reading or literary interpretation, that is, the phenomenon of parolization can be understood more precisely if it is considered under the categories of Linguistics of Saying, as formulated by Jesús Martínez del Castillo, that is, the linguistics of the speech act including speaking, saying and knowing.

Indeed, in an appendix to his article "The Speech Act as an Act of Knowing", Martínez del Castillo presents an exhaustive chart of the phenomenon. In the end, he describes it like

3 Ibid, p. 331. My translation

4 Ibid, p. 333. 
this:

The act of knowing starts with an initial intuition or aisthesis. Then the subject selects from his aísthesis, thus making the thing selected abstract. Then it is delimited and assigned to a class of semantic objects thus making it virtual. It is related to other meanings in the tradition. Then it is given a name and determined thus making it objective and eventually with the linguistic expression it is made real5.

Removing the final parts (determination and expression), the process goes from the concrete to the abstract. Parolization, however, is a process that goes from the abstract to the concrete. A text is a virtual reality, as Saussure's langue or Coseriu's system, a reality conceptually woven; interpretation, an activity making the text into actual and imaginative, such as parole or speaking. In Martínez del Castillo's words:

The listener [we could extend the term to the reader], on the contrary, starts with the historical means [that is, the language of the text] and his initial apprehension of the thing said and then interprets it thus creating an aisthesis of his own mentally and eventually contents of conscience 6 .

Martínez del Castillo identifies three aspects on his Linguistics of Saying: knowing, saying and speaking. He offers the following definitions:

Language is cognizant activity embracing, a) Knowing or the way the human subject approaches reality in order to apprehend and dominate it in the sense the most convenient to him in the circumstance he is in; b) Saying or the interior activity of the subject consisting in rearranging those things known to him thus constituting himself in the guarantee of that systematization made on the things known, that is, compromising before and with them; and c) Speaking with the implicit search of traditional means of expression in order to say something of the things known. Language, thus, is the activity consisting of knowing, saying and speaking by a subject who is in a particular circumstance 7 .

A text, then, is the result of the knowing, saying and speaking of a free subject that executes his liberty thus creating. Accordingly, the reading, the interpretation, the parolization of the text is the activity of another free and creative subject. It implies knowing and saying and, eventually, if it manifests itself as a paraphrase, let`s say, "public" paraphrase, as speaking as well.

Apparently, we are dealing with simple operations that guarantee a fluid and precise interaction between text and interpreter, as intended, for example, by a particular version of information theory. However, as knowing, saying and speaking cross themselves, the chances of misunderstanding are high, much higher in any case than simplistic theories state, the theories considering transmitters and receivers as mere "containers" of content. As Martínez del Castillo holds about:

...[a] linguistic expression is ambiguous: one thing is the thing said, something else is the thing meant, and something else is

5 Martínez del Castillo, 2015c, p. 37.

6 Martínez del Castillo, 2015a, p. 28

7 Martínez del Castillo, 2015b, p. 6. the thing understood. If the act of apprehending and conceiving things on the one hand, and understanding in the other, is individual by definition, the interchange between the speaker and the listener is possible but with the limitation said: we speak in essences and apply the essences created to the things we apprehend. What we apprehend on the one hand, the thing we say of on the other, and the things we refer to on the other, constitute objects with different nature incompatible with each other8.

\section{Aspects of Parolization}

We want to call the reader's attention on the phenomenon of parolization considering Martínez del Castillo's distinctions: what we apprehend, the things we say and the things we refer to. First, it could be argued that artists not only do they grasp reality in a certain way, that they not only do know or apprehend reality, but as Eugenio Coseriu states, they do "make"9 it, they do create it. More than saying with language (or with a language) artists "create" with a language and through a language. Indeed, an author can refer to extra-verbal reality and the reader cannot help but considering it in his interpretation if he aspires to be exhaustive. One will not fully understand the poem "A José María Palacio" by Antonio Machado published in his book Campos de Castilla (Castilian Fields) 10 unless he knows that, in the final exhortation, "el Espino" ("the Hawthorn") is not any high place but Soria's cemetery, where Leonor Izquierdo, the poet's young wife, who died of tuberculosis prematurely, lays buried. This piece of information fits with other "objective" values of the terms of the text: the interlocutors are two friends, one who is in Soria (Palacio) and the other one in Baeza (Machado himself). The final date indicates that it is the first anniversary of the death of the poet's beloved. In this case parolization should incorporate extra-linguistic data for the understanding of the text. As with philological commentary, knowing the language is not enough to interpret a text. It is also necessary to know things. Part, then, of literary competence - as with non-literary linguistic competence - consists in the incorporation of extra-linguistic data to the exegesis of the text. Understanding, however, is fully linguistic.

Other examples may have a more autonomous linguistic reality. In certain dramatic or para-dramatic texts, it is the text itself that generates the reality it refers to, as it is the case in Fernando de Rojas' La Celestina:

CELESTINA. Climb then quickly to the high attic of the corridor and bring me the pot of serpentine oil here; you'll find it hanging from the piece of rope I brought from the fields that night when it rained and was dark. Open the ark of threads and on the right hand direction you'll find a piece of paper written with bat blood under the wing of that dragon from which we took the nails offyesterday. Look, don't spill the May water they

8 Martínez del Castillo, 2015a, p. 28.

9 "One must insist, then, that literary discourse does not 'inform': it 'does". (Coseriu, 2006, p. 94). My translation.

10 Machado, 1997a, pp. 187-188. 


\section{brought to me to prepare11.}

In the previous text, linguistic phenomena such as deixis or the use of articles create extra-verbal reality, the reality of things referred to by Celestina's discourse. Celestina speaks of objects as things previously known. For expressing this feature, the writer uses the article: "the high attic of the corridor" or "the pot of serpentine oil" are places or things known to Elicia and Celestina and, since they are named, they are also known to the readers of the text. "Here" and "on the right hand" are indications that open imaginative spaces as these are enunciated. For parolization to work, the interpreter must suspend the evidence that "there's nothing there" and imagine precisely that "there's something there". Referring in this case to Martínez del Castillo's distinctions, authors show their effectiveness by saying and speaking. And in connection with readers, by saying and speaking of the knowledge of a reality really arising only in words.

Other aspects of literary competence -indicators of the measure of effective parolization - relate to strictly literary knowledge (a kind of technique or art 12) the interpreter should handle. A typical case of this, as Trabant observed, is the segmentation of textual units. It is the case of identifying the exordium in epic poems. The first ten verses of the Odyssey, for example, make a clear preface. The debuts of the second canto of Inferno and the first cantos of Purgatory and Paradise of Dante's Comedy are patent. However, the delimitation of the exordium of Inferno, canto XIX, may not be as clear. If the first six verses of this canto can easily be recognized as a prologue or preface, there are reasons to prolong the textual unit to verse 10 , where the repeated exhortation could signal the end of this part. In connection with this it can be mentioned the identification of endings as well (epilogues, for example, and some other textual units) as Frank Kermode studies them in his book The Sense of an Ending. The final couplet of the English or Shakesperian sonnet is probably the most distinctive feature in English literary tradition in contrast to the Petrarchan sonnet - a sonnet that should be called "Italian sonnet" since it was used by Dante and other early Italian authors. In parolization the interpreter must identify and highlight when the text finishes or has the appropriate cohesion.

This applies, too, to various phenomena of the literary tradition concerning the metric or rhythmic interpretation of texts. Spanish verses are formed following the model of paroxytonic words. If a verse ends in an oxytonic word, a syllable must be added; if it ends in a proparoxytonic word, a syllable must be substracted; but if it ends in a paroxytonic word, it will be kept unmodified. Such knowledge is relevant to ensure the isometry of certain types of Spanish verses and the metrical or rhythmical effect they point out to thus forming part of the traditional literary knowledge (i.e., literary competence): an

11 Rojas, 2000, p. 106. My translation.

12 Clearly a cognitio clara distincta inadequata, in Leibnitz' categories as assumed by Coseriu (1992). It is not enough a non-motivated knowledge here, but, at the same time, it's neither a knowledge with a justification one should expect from a Literary Theory Scholar. interpreter should execute it in an adequate parolization 13.

It is even more difficult to find skilled interpreters that can adequately segment Spanish "verso compuesto" (compound verse). Even though this kind of verse is based on a recognizable feature of Spanish prosody, the boundary between stress-groups, this is not an obvious phenomenon14 and many readers in their parolization skip the caesura pause that separates one hemistich from another. They also frequently skip enjambments. Consider these verses from Rubén Darío:

Maravillosamente danzaba. / Los diamantes

negros de sus pupilas/vertían su destello:

[...]

Ornábase con rojos/ claveles detonantes

la redondez oscura/ del casco del cabello15.

In the first two verses, we can recognize one enjambment between the last word of the first verse ("diamantes") and the first word of the second ("negros"). "Los diamantes" and "negros" form a sirrem (in Spanish, sirrema), a melodic-syntactic unit indivisible in Spanish16. The versal pause, separating verse from verse, however, severs the sirrem and causes a portion of it to remain in the first verse and the other one in the second. An inadvertent parolization would tend to respect the sirrem not respecting the verse division. On the contrary, an all too aware parolization respects the versal pause and destroys the sirrem. A subtle interpreter must give the impression that the versal pause is maintained and, simultaneously, that the sirrem is preserved (e.g., with an elongation of the final syllable and a melodic suspension). The phenomenon could also occur between hemistichs in verso compuesto: as one can see (see the last two verses), there is enjambment between "rojos" and "claveles". And the interpreter should seek to make a run to generate the same effects as those produced with versal enjambment.

This literary knowledge - literary competence - is essential for the proper execution, for the parolization of the text thus including time constraints. The interpreter should know, because this is not an information appearing in all editions, that Gonzalo de Berceo's poetry should be recited without considering synalepha, that is, the union - some times a diphthong - formed by the two contiguous vowels of two contiguous words. A patent "metrical habit" not present in the text, although essential for its execution is the one of the actualization of the paragogic "e" in Medieval epic poetry, as shown by this fragment of the Cantar de Mio Cid:

Grand iantar le fazen al buen Campeadore; tañen las campanas en San Pero a clamore. Por Castiella oyendo van los pregones 17.

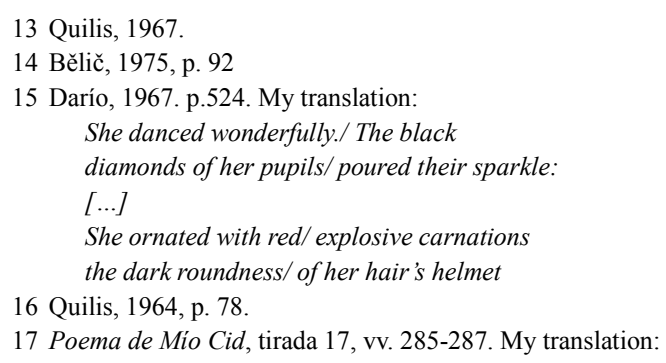


Some editions of the Cantar de Mío Cid (Menéndez Pidal's, for example) include this " $\mathrm{e}$ " in the text. The paragogic " $\mathrm{e}$ " is an aggregation in this case vocalic, etymological or not, which is included at the end of some verses of Medieval Castilian epic poems. This "e" is not in the original manuscript and it is not registered in several modern editions, such as Alberto Montaner's, Ian Michael's or Colin Smith's. The interpreter should include it to keep assonant rhyme (in this case, $o-e$ ) of the series (in Spanish, "tirada"; in French, "laisse").

Finally a text as a product of a free act is not excluded from having errors or mysteries, so that ambiguity 18 , always possible in exegesis, is never ruled out. Consider, for example, this fragment from a poem by Antonio Machado:

$$
\begin{aligned}
& \text { [...] } \\
& \text { En esas galerías } \\
& \text { sin fondo, del recuerdo, } \\
& \text { donde las pobres gentes } \\
& \text { colgaron cual trofeo } \\
& \text { el traje de una fiesta } \\
& \text { apolillado y viejo, } \\
& \text { alli el poeta sabe } \\
& \text { el laborar eterno } \\
& \text { mirar de las doradas } \\
& \text { abejas de los sueños } 19 .
\end{aligned}
$$

As it sometimes happens in hermeneutics, it becomes clearer, in this part of the Machadian text, intuiting the sense than giving timely notice of the meanings. The sense of "el laborar eterno/ mirar de las doradas/ abejas de los sueños"20 refers to the incessant activity of the poet's imaginative creation, which, being linked to dreams, is simultaneously, strange and homely. However, it is difficult to account for the grammatical meaning of the phrase "laborar eterno mirar" 21 , because linking the adjective "eterno" with either infinitives, one of them will always remain loose: if it bonds with "laborar" and it is said "laborar eterno", "mirar" remains loose and its syntactic function is incomprehensible in this context; if it bonds with "mirar" and it is said "eterno mirar", "laborar" remains loose and its syntactic function, undecipherable. Maybe the impasse could be resolved by punctuating the text adding commas. So, the text should look like this: "el laborar,

Great banquet they make to the good Campeador;

the bells toll at San Pedro with clamor.

Through Castille the proclamations are heard

18 Cfr. Martínez del Castillo, 2015b.

19 Machado, 1989 , vv. 15-24. My translation:

$$
\text { [...] }
$$

In these galleries,

bottomless, of remembrance,

where poor people

hung like a trophy

the costume of a party,

moth-eaten and old,

the poet knows there

the eternal labor

look of the golden

bees of dreams.

20 Ibid, vv. 22-24.

21 Ibid, vv. 22-23. eterno mirar, de las doradas abejas de los sueños". Thus, the grammaticality of the sequence is guaranteed: "eterno mirar" depends syntactically of "laborar". This is the work usually carried out by text editors. However, there is no documentary support to include such innovation. None of the four editions of the Complete Poems by Antonio Machado or the several editions of Soledades, as the philological collation by Oreste Macrì certifies, record variations of these verses. Consequently, the reader, the interpreter, the editor, has no choice but leaving the text as it is and assuming the necessary imperfection of his or her parolization.

\section{References}

[1] Berceo, Gonzalo de, Milagros de Nuestra Señora. Edición de Fernando Baños. Estudio preliminar de Isabel Uría. Barcelona: Crítica, 1997.

[2] Bělič, Oldrich, En busca del verso español. Praha: Univerzita Karlova, 1975.

[3] Cantar de Mio Cid. Edición de Alberto Montaner. Estudio preliminar de Francisco Rico. Barcelona: Crítica, 2000.

[4] Cantar de Mío Cid. Texto, Gramática y vocabulario por R. Menéndez Pidal. Madrid: Espasa-Calpe, 1969.

[5] Coseriu, Eugenio, Competencia lingüistica. Elementos de la teoria del hablar. Madrid: Gredos, 1992.

[6] Coseriu, Eugenio, "Información y literatura" en Coseriu, Eugenio y Óscar Loureda Lamas. Lenguaje y discurso. Pamplona: EUNSA, 2006: 85-99.

[7] Darío, Rubén, Poesías completas. Ordenadas por Luis Alberto Ruiz. Buenos Aires: Antonio Zamora, 1967.

[8] Kermode, Frank, The Sense of an Ending. Studies in the Theory of Fiction, Oxford-New York: Oxford University Press, 2000.

[9] Lázaro Carreter, Fernando, Diccionario de términos filológicos. Madrid: Gredos, 1971.

[10] Machado, Antonio, Campos de Castilla (1907-1917). Edición de Geoffrey Ribbans. Madrid, Cátedra, 1997a.

[11] Machado, Antonio, Poesía y prosa. Tomo II: Poesías completas. Edición crítica de Oreste Macrì con la colaboración de Gaetano Chiappini. Madrid: Espasa-Calpe - Fundación Antonio Machado, 1989.

[12] Machado, Antonio, Soledades. Galerías. Otros poemas. Edición de Geoffrey Ribbans. Madrid: Cátedra, 1997b.

[13] Martínez del Castillo, Jesús, "Fixing the Content Created in the Act of Knowing". International Journal of Language and Linguistics 2015a; 3 (6-1): 24-30

[14] Martínez del Castillo, Jesús, "The Meaningful Intentional Purpose of the Individual Speaker". International Journal of Language and Linguistics 2015b; 3 (6-1): 5-10

[15] Martínez del Castillo, Jesús, "The Speech Act as an Act of Knowing". International Journal of Language and Linguistics 2015c; 3(6-1): 31-38.

[16] Poema de Mio Cid, Edición, introducción y notas de Ian Michael. Madrid: Castalia, 1973. 
[17] Poema de Mio Cid. Edición de Colin Smith. Madrid: Cátedra, 1981.

[18] Rojas, Fernando (y "antiguo autor"), La Celestina. Tragicomedia de Calisto y Melibea. Edición y estudio de Francisco J. Lobera y Guillermo Serés, Paloma Díaz-Mas, Carlos Mota e Íñigo Ruiz Arzálluz y Francisco Rico. Barcelona: Crítica, 2000.

[19] Trabant, Jürgen, Semiología de la obra literaria. Glosemática y teoría de la literatura. Madrid: Gredos, 1975.
[20] Quilis, Antonio, Estructura del encabalgamiento en la métrica española. Madrid: Consejo Superior de Investigaciones Científicas, 1964

[21] Quilis Antonio, "Sobre la percepción de los versos oxítonos, paroxítonos y paroxítonos en español" en Revista de Filología Española, L, 1967, p. 273-286. 